\title{
Influence of oxidative stress, diaphragm fatigue, and inspiratory muscle training on the plasma cytokine response to maximum sustainable voluntary ventilation
}

Dean E. Mills, Michael A. Johnson, Martin J. McPhilimey, Neil C. Williams, Javier T. Gonzalez, Yvonne A. Barnett and Graham R. Sharpe J Appl Physiol 116:970-979, 2014. First published 20 February 2014; doi:10.1152/japplphysiol.01271.2013

You might find this additional info useful...

This article cites 70 articles, 35 of which can be accessed free at: /content/116/8/970.full.html\#ref-list-1

Updated information and services including high resolution figures, can be found at: /content/116/8/970.full.html

Additional material and information about Journal of Applied Physiology can be found at: http://www.the-aps.org/publications/jappl

This information is current as of October 13, 2014. 


\title{
Influence of oxidative stress, diaphragm fatigue, and inspiratory muscle training on the plasma cytokine response to maximum sustainable voluntary
} ventilation

\author{
Dean E. Mills, ${ }^{1}$ Michael A. Johnson, ${ }^{1}$ Martin J. McPhilimey, ${ }^{1}$ Neil C. Williams, ${ }^{1}$ Javier T. Gonzalez, ${ }^{2}$ \\ Yvonne A. Barnett, ${ }^{1}$ and Graham R. Sharpe ${ }^{1}$ \\ ${ }^{1}$ Sport, Health and Performance Enhancement (SHAPE) Research Group, School of Science and Technology, Nottingham \\ Trent University, Nottingham, United Kingdom; and ${ }^{2}$ School of Life Sciences, Northumbria University, Newcastle upon Tyne, \\ United Kingdom
}

Submitted 18 November 2013; accepted in final form 14 February 2014

Mills DE, Johnson MA, McPhilimey MJ, Williams NC, Gonzalez JT, Barnett YA, Sharpe GR. Influence of oxidative stress, diaphragm fatigue, and inspiratory muscle training on the plasma cytokine response to maximum sustainable voluntary ventilation. $J$ Appl Physiol 116: 970-979, 2014. First published February 20, 2014; doi:10.1152/japplphysiol.01271.2013.-The influence of oxidative stress, diaphragm fatigue, and inspiratory muscle training (IMT) on the cytokine response to maximum sustainable voluntary ventilation (MSVV) is unknown. Twelve healthy males were divided equally into an IMT or placebo (PLA) group, and before and after a 6-wk intervention they undertook, on separate days, $1 \mathrm{~h}$ of (1) passive rest and (2) MSVV, whereby participants undertook volitional hyperpnea at rest that mimicked the breathing and respiratory muscle recruitment patterns commensurate with heavy cycling exercise. Plasma cytokines remained unchanged during passive rest. There was a main effect of time $(P<0.01)$ for plasma interleukin-1 $\beta$ (IL-1 $\beta)$ and interleukin-6 (IL-6) concentrations and a strong trend $(P=0.067)$ for plasma interleukin-1 receptor antagonist concentration during MSVV. Plasma IL- 6 concentration was reduced after IMT by $27 \pm 18 \%$ (main effect of intervention, $P=0.029$ ), whereas there was no change after PLA $(P=0.753)$. There was no increase in a systemic marker of oxidative stress [DNA damage in peripheral blood mononuclear cells (PBMC)], and diaphragm fatigue was not related to the increases in plasma IL-1 $\beta$ and IL-6 concentrations. A dose-response relationship was observed between respiratory muscle work and minute ventilation and increases in plasma IL-6 concentration. In conclusion, increases in plasma IL-1 $\beta$ and IL-6 concentrations during MSVV were not due to diaphragm fatigue or DNA damage in PBMC. Increases in plasma IL-6 concentration during MSVV are attenuated following IMT, and the plasma IL- 6 response is dependent upon the level of respiratory muscle work and minute ventilation.

cytokine; respiratory muscles; ventilation

WE RECENTLY DEMONSTRATED THAT plasma interleukin-6 (IL-6) concentration increased when young, healthy adults undertook $1 \mathrm{~h}$ of volitional hyperpnea at rest that mimicked the breathing and respiratory muscle recruitment patterns commensurate with cycling exercise undertaken at an estimated maximum lactate steady-state intensity (42). This finding supports the notion that the respiratory muscles may contribute to systemic increases in plasma IL-6 concentration observed when the intensity of respiratory muscle work is increased such as in strenuous whole-body exercise, asthma attacks, and exacerba-

Address for reprint requests and other correspondence: D. Mills, Queensland Children's Medical Research Institute, The Univ. of Queensland, Royal Children's Hospital, Brisbane, Australia, 4029 (e-mail: d.mills2@uq.edu.au). tions of chronic obstructive pulmonary disease (COPD) (34, 48, 71).

We also demonstrated that volitional hyperpnea elevated plasma IL-6 concentrations in the absence of diaphragm fatigue, and that inspiratory muscle training (IMT) reduced the plasma IL-6 response to exercise but not volitional hyperpnea (42). Whether other plasma cytokines may be affected by such interventions is unknown. Whole-body exercise and inspiratory resistive loading (IRL) can increase the plasma concentration of the proinflammatory cytokine interleukin-1 $\beta$ (IL-1 $\beta$ ) and IL-6 $(45,66,67)$. Within the diaphragm of rats exposed to IRL, IL-1 $\beta$ and IL- 6 are stimulated by oxidative stress and possibly diaphragm fatigue $(56,57,65)$.

IL-1 $\beta$ can impair striated muscle function and potentially reduce muscle contractility (37). IL-1 $\beta$ may also have a role within muscle repair and regeneration following injury. The IL-1 $\beta$ gene is activated with strenuous muscular contraction, and the associated micro injury that occurs within the muscle stimulates quiescent resident macrophages to secrete IL-1 $\beta$ $(11,17,21,51,64)$. IL-1 $\beta$ also stimulates proteolysis and acts a chemoattractant for macrophages which can phagocytize cellular debris and provide a large source of growth factors which may stimulate myogenesis $(11,17,21,51,64)$. Therefore, oxidative stress, respiratory muscle fatigue/injury, and repair/regeneration may be stimuli for the production of IL-1 $\beta$ by human respiratory muscles. In addition, since respiratory muscle training attenuates exercise-induced diaphragm fatigue during whole-body exercise (68), IMT may also reduce IL-1 $\beta$ production by the inspiratory muscles.

Whole-body exercise also increases the plasma concentration of the anti-inflammatory cytokine interleukin-1 receptor antagonist (IL-1ra) $(45,54,72)$. IL-1ra is stimulated by IL-6 and IL-1 $\beta$ and acts to restrict and limit the extent of the inflammatory response by inhibiting signaling transduction of interleukin-1 through the interleukin-1 receptor complex (18, 62). Recent evidence has demonstrated that the plasma IL-1ra response to exercise is attenuated following whole-body endurance training (72). This may be due to a training-induced reduction in IL-6 and/or IL- $\beta$ which may also occur following IMT.

The maximum lactate steady state represents the highest work rate at which a physiological steady state can be achieved and, therefore, marks the boundary between sustainable and nonsustainable work rates $(30,31)$. The minute ventilation ( $\left.\dot{V}_{E}\right)$ associated with the maximum lactate steady state is known to be well below an individual's maximum sustainable 
voluntary ventilation (MSVV) (31) and, therefore, our previously reported breathing-induced plasma IL- 6 response may have been submaximal (42). The notion that inflammatory responses to respiratory muscle work and $\dot{V}_{E}$ may be dose dependent is supported by the observation that increases in plasma IL-6 concentration are intensity dependent during whole-body exercise $(47,54)$. Therefore, an aim of this study was to examine the response of plasma cytokines IL-1 $\beta$, IL-1ra, and IL-6 to MSVV, whereby participants undertook volitional hyperpnea at rest that mimicked the breathing and respiratory muscle recruitment patterns commensurate with heavy cycling exercise. We also sought to examine the mechanism(s) for cytokine production by measuring diaphragm fatigue [known to be elicited by MSVV (3)] and a systemic marker of oxidative stress. Finally, we examined whether these responses were altered by IMT.

\section{METHODS}

Participants. Twelve nonsmoking recreationally active males provided written, informed consent to participate in the study which was approved by the Nottingham Trent University Human Ethics Committee. The characteristics, pulmonary function, maximal inspiratory pressure (MIP), maximum power output, and peak oxygen uptake of the study participants has been described previously (42). A selfreported medical questionnaire confirmed that participants were free from illness and injury and not taking any medication and/or antioxidant supplements during the study. Each participant completed a 24-h diet record prior to their first trial, which was then replicated prior to all subsequent trials. Throughout the study, participants were instructed to adhere to their habitual training regimen and not to engage in any strenuous exercise the day preceding, the day of, and in the 24 $\mathrm{h}$ following each trial. Participants arrived at the laboratory $4 \mathrm{~h}$ postprandially having abstained from alcohol and caffeine in the $24 \mathrm{~h}$ before testing.
Experimental design. Participants attended the laboratory on three separate occasions, before and after a 6-wk intervention (Fig. 1). Each laboratory visit was separated by $48 \mathrm{~h}$ and took place at the same time of day. During the first visit, participants were familiarized with all testing procedures and pulmonary function, and MIP were measured. During the second visit, participants performed a maximal incremental cycling test. The subsequent two experimental trials were randomized, lasted $1 \mathrm{~h}$ and comprised (1) passive rest (PASSIVE) and (2) MSVV. Thereafter, participants were randomly, and equally, divided into an IMT or placebo (PLA) group and completed the intervention. At least 48-h postintervention, participants repeated the maximal incremental cycling test and experimental trials in the same order as preintervention. All trials were performed on an electromagnetically braked cycle ergometer (Excalibur Sport, Lode, Groningen, The Netherlands).

Pulmonary function and maximal inspiratory mouth pressure. Pulmonary function was assessed according to published guidelines (41) using a pneumotachograph (Pneumotrac, Vitalograph, Buckingham, UK) calibrated with a 3-1 syringe. A hand-held mouth pressure meter (MicroRPM, CareFusion, Basingstoke, UK) measured MIP as an index of global inspiratory muscle strength. The mouthpiece assembly incorporated a 1-mm orifice to prevent glottic closure during inspiratory efforts. Maneuvers were performed while standing, initiated from residual volume, and sustained for at least $1 \mathrm{~s}$. Repeat efforts separated by $30 \mathrm{~s}$ were performed until three serial measures differed by no more than $10 \%$ or $10 \mathrm{cmH}_{2} \mathrm{O}$, whichever was smallest $(8,10,28)$. The highest value recorded was used for subsequent analysis.

Maximum incremental cycling test. Cycling began at $0 \mathrm{~W}$, and power was subsequently increased by $10 \mathrm{~W}$ every $15 \mathrm{~s}$ in order to result in exercise intolerance within $\sim 10 \mathrm{~min}$. This rapid incremental protocol was selected to maximize $\dot{\mathrm{V}}_{\mathrm{E}}$ at the cessation of the test and, therefore, reflect heavy exercise. The power at which exercise intolerance ensued defined maximum power output, and the highest $\dot{V}_{E}$ and oxygen uptake recorded in any $30 \mathrm{~s}$ period defined peak $\dot{\mathrm{V}} \mathrm{E}$ ( $\left.\dot{\mathrm{V}}_{\text {peak }}\right)$ and peak oxygen uptake, respectively.

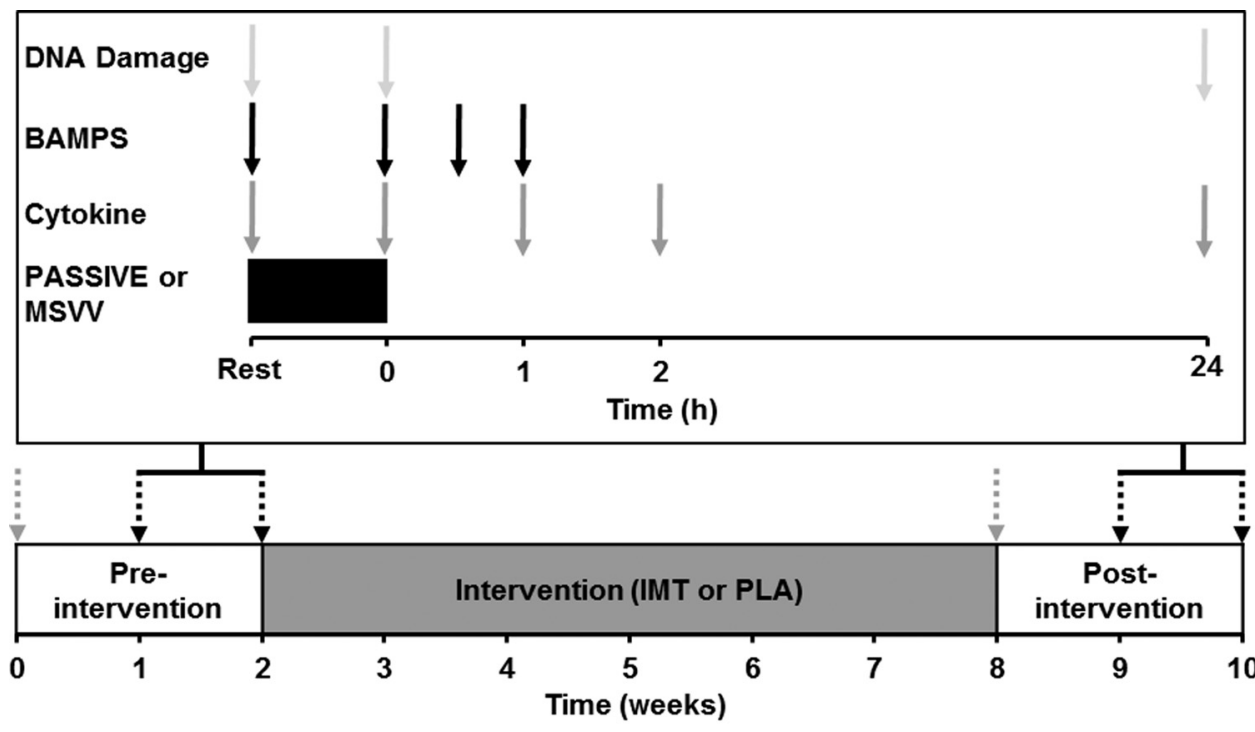

Fig. 1. Schematic of experimental design.

Maximal incremental cycling test

Cytokine, blood sample for cytokines

DNA Damage, blood sample for DNA damage in peripheral blood mononuclear cells
Experimental trial (PASSIVE or MSVV)

BAMPS, bilateral anterior magnetic phrenic nerve stimulation 
Experimental trials. During experimental trials, the configuration of the cycle ergometer and the body position adopted by each participant were identical to those adopted during the maximal incremental cycling test. MSVV was preceded by a 5-min rest period, and during PASSIVE participants remained seated on the cycle ergometer for the duration of the trial. During MSVV participants undertook volitional hyperpnea at rest that mimicked the breathing [tidal volume $\left(\mathrm{V}_{\mathrm{T}}\right)$; breathing frequency $\left(f_{\mathrm{B}}\right)$; and duty cycle $\left.\left(\mathrm{T}_{\mathrm{I}} / \mathrm{T}_{\mathrm{TOT}}\right)\right]$ and respiratory muscle recruitment [peak transdiaphragmatic pressure $\left(\mathrm{P}_{\text {dipeak }}\right)$ ] patterns commensurate with heavy cycling exercise. These variables were determined from the average values obtained between $70-80 \%$ of the $\dot{V}_{\text {peak }}$ attained during the preintervention maximal incremental cycling test; pilot work showed that this represented the maximum voluntary ventilation that could be sustained for $1 \mathrm{~h}$. During the postintervention MSVV trial, participants mimicked the breathing and respiratory muscle recruitment patterns performed during the preintervention MSVV trial. An audio metronome paced $f_{\mathrm{B}}$ and $\mathrm{T}_{\mathrm{I}} / \mathrm{T}_{\mathrm{TOT}}$, and real-time visual feedback of $\mathrm{V}_{\mathrm{T}}$ and $\mathrm{P}_{\text {dipeak }}$ was provided throughout. The use of $\mathrm{P}_{\text {dipeak }}$ targets allowed us to more precisely control the mechanical work of breathing during $\operatorname{MSVV}(3,35)$. All experimental trials were performed in an environmental chamber (Design Environmental WIR52-20HS, Design Environmental, Ebbw Vale, UK) at $20^{\circ} \mathrm{C}$ and $90 \%$ relative humidity to minimize mucosal drying during MSVV (42).

Flow, pulmonary gas exchange, and pressure measurements. During all trials participants wore a facemask (model 7940, Hans Rudolph, Kansas City, MO) connected to a flow sensor (ZAN variable orifice pneumotach, Nspire Health, Oberthulba, Germany) that was calibrated using a 3-1 syringe. Gas concentrations were measured using fast responding laser diode absorption spectroscopy sensors, which were calibrated using gases of known $\left(5 \% \mathrm{CO}_{2}, 15 \% \mathrm{O}_{2}\right.$ and balance $\mathrm{N}_{2}$ ) concentrations (BOC, Guildford, UK), and ventilatory and pulmonary gas exchange variables were determined breath-bybreath (ZAN 600USB, Nspire Health). During experimental trials a two-way nonrebreathing valve (model 2730, Hans Rudolph) was attached distally to the pneumotachograph, and a $1.5-\mathrm{m}$ length of wide-bore tubing was connected to the inspiratory port. During MSVV, $\mathrm{CO}_{2}$ was added into this tubing to increase $\mathrm{F}_{\mathrm{I}} \mathrm{CO}_{2}$ and thus retain end-tidal and, consequently, blood $\mathrm{PCO}_{2}$ at levels commensurate with rest $(9,31)$. On the expiratory port of the two-way valve a Fleisch no. 3 pneumotachograph was attached and connected to a differential pressure transducer $\left( \pm 2.5 \mathrm{cmH}_{2} \mathrm{O}\right)(\mathrm{TSD} 160 \mathrm{~A}, \mathrm{BIOPAC}$ Systems, Goleta, CA) and differential bridge amplifier (DA100C, BIOPAC Systems) to allow alignment of flow and pressure signals. Esophageal $\left(\mathrm{P}_{\mathrm{e}}\right)$ and gastric $\left(\mathrm{P}_{\mathrm{ga}}\right)$ pressures were measured and calibrated as described previously (42). Transdiaphragmatic pressure $\left(\mathrm{P}_{\mathrm{di}}\right)$ was calculated by subtracting $\mathrm{P}_{\mathrm{e}}$ from $\mathrm{P}_{\text {ga }}$. As an estimate of respiratory muscle work, $\mathrm{P}_{\mathrm{di}}$ and $\mathrm{P}_{\mathrm{e}}$ were integrated over the period of inspiratory flow and multiplied by $f_{\mathrm{B}}$ and labeled the diaphragm pressure-time product $\left(\mathrm{PTP}_{\mathrm{di}}\right)$ and the inspiratory muscle pressure-time product $\left(\mathrm{PTP}_{\mathrm{e}}\right)$, respectively. Nonphysiological flows and pressures that resulted from swallowing, coughing, and breath holding were identified by visual inspection and removed. Breathing mechanics data were ensemble averaged into six 10-min blocks and used for subsequent analysis.

Bilateral anterior magnetic phrenic nerve stimulation. Bilateral anterior magnetic phrenic nerve stimulation (BAMPS) (43) was applied using two double 25-mm coils connected to two Magstim $200^{2}$ stimulators (Magstim, Whitland, UK) as described previously (42). To determine supramaximal phrenic nerve stimulation, three single twitches were obtained every $30 \mathrm{~s}$ at intensities of 50, 60, 70, 80, 85, 90,95 , and $100 \%$ of maximal stimulator output. A plateau in transdiaphragmatic twitch pressure $\left(\mathrm{P}_{\text {ditw }}\right)$ and $\mathrm{M}$-wave responses with increasing stimulation intensities indicated maximum depolarization of the phrenic nerves. $\mathrm{P}_{\text {ditw }}$ was assessed every $30 \mathrm{~s}$ using eight single stimuli at $100 \%$ of maximal stimulator output. $\mathrm{P}_{\text {ditw }}$ was measured at baseline and within 15 (<15 $\mathrm{min}), 35$ ( $<35 \mathrm{~min})$, and 60 (<60 min) min after each experimental trial. Additionally, $\mathrm{P}_{\mathrm{ditw}}$ at each measurement point was followed by the assessment of the potentiated $\mathrm{P}_{\mathrm{ditw}}$ response. Participants performed a 3-s maximal Müeller maneuver and $\sim 5 \mathrm{~s}$ later a single stimuli was delivered. This procedure was repeated six times with each measure separated by $30 \mathrm{~s}$. The average of the median three individual $\mathrm{P}_{\mathrm{ditw}}$ responses were used for analysis. Diaphragm fatigue was defined as a $>15 \%$ reduction in $\mathrm{P}_{\text {ditw }}$ compared with the baseline value $(36,42)$.

Measurement of systemic oxidative stress. Arterialized venous blood was sampled from a dorsal hand vein via an indwelling 21-G cannula (40). Arterialization was ensured by immersing the hand in water at $40^{\circ} \mathrm{C}$ for $10 \mathrm{~min}$ prior to cannulation and by warming the hand during trials using an infrared lamp. Levels of systemic oxidative stress were determined using the Comet Assay, which can measure oxidative DNA damage in peripheral blood mononuclear cells (PBMC). Previously, data has reported an increase in systemic DNA damage following heavy cycling exercise using the Comet Assay (49, 69). During the experimental trials, 5 -ml blood samples were taken at rest, immediately following the experimental trial $(0 \mathrm{~h})$ and 1 day into recovery $(+24 \mathrm{~h})$. Blood was immediately transferred into precooled tubes containing lithium heparin (SARSTEDT, Leicester, UK). PBMC were isolated using density gradient centrifugation. The heparinized venous blood was mixed with $5 \mathrm{ml}$ of phosphate buffered saline and layered onto a lymphocyte separation medium (FicollPaque Plus, Griener Bio-One, Stonehouse, UK) inside a Leucosep tube (Griener Bio-One) and centrifuged for $15 \mathrm{~min}$ at $800 \mathrm{~g}$ and room temperature. The opaque mononuclear cell layer was aspirated and washed 3 times in phosphate buffered saline and centrifuged for 10 $\min$ at $200 \mathrm{~g}$ and room temperature. The cells were cryopreserved in liquid nitrogen for subsequent analysis in a medium consisting of $10 \%$ Dimethyl sulfoxide (Sigma-Aldrich, Gillingham, UK), 20\% fetal bovine serum (Invitrogen, Paisley, UK) and 70\% X-Vivo 10 media (Lonza, Wokingham, UK).

Levels of DNA damage (DNA single-strand breaks and alkali labile lesions) in PBMC were determined in duplicate using the alkaline Comet Assay (59) and the modified alkaline Comet Assay (15) as described by Marthandan et al. (38). In the modified Comet Assay, PBMC embedded on slides were treated with either formamidopyrimidineglycosylase (FPG) which recognizes oxidatively modified purines (6), or with endonuclease III (ENDO III) which recognizes oxidatively modified pyrimidines (2). These enzymes nick DNA at the sites of oxidatively damaged nucleotides, creating single-strand breaks which can be detected with the alkaline Comet Assay. PBMC treated with $150 \mu \mathrm{M}$ of hydrogen peroxide for $5 \mathrm{~min}$ at $4^{\circ} \mathrm{C}$ (to induce oxidative damage) were used as internal positive controls in the modified alkaline Comet Assay.

The Comet Assays were performed at $4^{\circ} \mathrm{C}$ to minimize the repair of existing basal levels of DNA damage present in PBMC. PBMC $(2 \times$ $10^{4}$ cells/gel) were embedded in a $1 \%$ agarose gel on frosted microscope slides and lysed for $1 \mathrm{~h}$ in a high salt alkaline buffer $[2.5 \mathrm{M}$ sodium chloride, 0.1 M EDTA, 0.01 M Tris, 1\% (v/v), Triton X-100, $\mathrm{pH}$ 10]. For the modified Comet Assays, slides were equilibrated in enzyme buffer (0.04 M HEPES, 0.1 M potassium chloride, $0.5 \mathrm{mM}$ EDTA, $0.2 \mathrm{mg} / \mathrm{ml}$ bovine serum albumin, $\mathrm{pH}$ 8.0) prior to the application of FPG or ENDO III. Slides treated with the lesion specific enzymes were incubated at $37^{\circ} \mathrm{C}$ in a humid, dark chamber for $45 \mathrm{~min}$. Following enzyme treatment (or immediately after alkaline lysis for the alkaline Comet Assay), the slides were placed in electrophoresis buffer (0.3 M sodium hydroxide, $1 \mathrm{mM}$ EDTA, $\mathrm{pH} \mathrm{13)} \mathrm{for} 20 \mathrm{~min}$, to allow alkaline unwinding of the DNA, and then electrophoresed at 25 $\mathrm{V}$ and $300 \mathrm{~mA}$ for $30 \mathrm{~min}$. Subsequently, slides were neutralized (0.4 $\mathrm{M}$ Tris, $\mathrm{pH} 7.5$ ) and stained (50 $\mu \mathrm{g} / \mathrm{ml}$ ethidium bromide) to visualize DNA. Stained slides were digitally analyzed using ultraviolet microscopy (Carl Zeiss, Welwyn Garden City, UK) and scored (50 PBMC per slide) using analysis software (Komet 5.5, Andor Bio Imaging, Nottingham, UK) by the same investigator. The interassay coefficient of variation $(\mathrm{CV})$ was $<10 \%$. 
Cytokines and additional blood analyses and measurements. At rest, immediately after $(0 \mathrm{~h})$ and $1(+1 \mathrm{~h}), 2(+2 \mathrm{~h})$, and $24(+24 \mathrm{~h})$ $\mathrm{h}$ after each experimental trial, $3 \times 5 \mathrm{ml}$ blood samples were taken for the measurement of plasma IL-1 $\beta$, IL-1ra, and IL- 6 concentrations. Blood was transferred into precooled tubes containing $1.6 \mathrm{mg} / \mathrm{ml}$ of $\mathrm{K}_{3}$ E EDTA (SARSTEDT) and immediately centrifuged for $15 \mathrm{~min}$ at $1,000 \mathrm{~g}$ and $5^{\circ} \mathrm{C}$. The plasma supernatant was subsequently removed and stored at $-80^{\circ} \mathrm{C}$ until further analysis. Commercial solid phase sandwich ELISA were used to measure plasma concentrations of IL-1 $\beta$, IL-6 (Quantikine HS, R\&D Systems Abingdon, UK), and IL-1ra (Quantikine, R\&D Systems) in duplicate. The assays have a detection limit of $0.1 \mathrm{pg} / \mathrm{ml}$ (IL-1 $\beta$ ), $22 \mathrm{pg} / \mathrm{ml}$ (IL-1ra), and 0.039 $\mathrm{pg} / \mathrm{ml}$ (IL-6), respectively. To minimize the effect of interassay variation, pre- and postintervention cytokines from both groups were measured during the same assay. The inter- and intra-assay $\mathrm{CV}$ for ELISA were $<10 \%$.

During the experimental trials, blood samples were taken at rest, every $3 \mathrm{~min}$ for the initial $15 \mathrm{~min}$, and every $5 \mathrm{~min}$ thereafter and analyzed immediately for $\mathrm{PCO}_{2}$ and $\mathrm{pH}$ (ABL520, Radiometer, Copenhagen, Denmark), which were corrected for changes in rectal temperature (Squirrel 2020, Grant Instruments, Cambridge, UK). At rest and every $10 \mathrm{~min}$ during each trial blood lactate concentration $\left(\left[\mathrm{La}^{-}\right]_{\mathrm{B}}\right.$ ) was determined using an automated analyzer (Biosen C-line Sport, EKF Diagnostics, Barleben, Germany), and measurements were taken for cardiac frequency $\left(f_{\mathrm{C}}\right)$ using short-range telemetry (Polar S610, Polar, Kempele, Finland), estimated arterial oxygen saturation $\left(\mathrm{SpO}_{2}\right)$ using infrared fingertip pulse oximetry (Model 8600, Nonin, Plymouth, MN), and dyspnea using Borg's modified CR10 rating of perceived exertion scale (7).

Inspiratory muscle training and placebo interventions. The intervention lasted $6 \mathrm{wk}$. The IMT group performed 30 consecutive dynamic inspiratory efforts twice daily using an inspiratory pressurethreshold device (POWERbreathe Classic series 1st generation, Gaiam, Southam, UK). The initial training load was 50\% MIP. Thereafter, participants periodically increased the load so that 30 maneuvers could only just be completed. Each inspiratory effort was initiated from residual volume and participants strove to maximize $\mathrm{V}_{\mathrm{T}}$. This regimen is known to be effective in eliciting an adaptive response (29, $42,52)$. The PLA group inhaled one puff twice daily from a sham metered dose inhaler (Vitalograph) (42). The inhaler contained compressed air only but was promoted to the participants as delivering a novel drug that reduces breathing-induced inflammation. During the postintervention period, the IMT and PLA groups performed their intervention $2 \mathrm{~d} / \mathrm{wk}$, which is sufficient to maintain improvements in inspiratory muscle function following IMT (52). These maintenance sessions were performed $48 \mathrm{~h}$ before and $48 \mathrm{~h}$ after experimental trials. All participants completed a training diary throughout the study to record adherence to the prescribed intervention and whole-body training sessions.

Statistical analyses. Statistical analyses were performed using SPSS for Windows (IBM, Chicago, IL). Normality of the data was assessed by visual inspection of histograms. In addition, skewness and kurtosis scores were converted to $Z$-scores by dividing them by their standard error. Resulting scores greater than 1.96 were considered to be significant. The majority $(>90 \%)$ of the data were normally distributed. Therefore, the data were not log-transformed and parametric statistics were used. Between- and within-group comparisons/ changes in baseline characteristics, including pulmonary function and MIP, were made using independent and paired $t$-tests, respectively. A three-way ANOVA was used to analyze the effects of "intervention" (pre- vs. post-"treatment") and "time" (10, 20, 30, 40, 50 and 60 min for breathing and respiratory muscle recruitment pattern and dyspnea data; rest 10, 20, 30, 40, 50, and $60 \mathrm{~min}$ for $\left[\mathrm{La}^{-}\right]_{\mathrm{B}}, \mathrm{pH}, \mathrm{PCO}_{2}, f_{\mathrm{C}}$, and $\mathrm{SpO}_{2}$ data; rest, 0 , and $+24 \mathrm{~h}$ for DNA damage data; rest, $0,+1,+2$, and $+24 \mathrm{~h}$ for plasma cytokine data; or baseline, $<15,<35$, and $<60$ min for $\mathrm{P}_{\text {ditw }}$ data) with a between-subject factor of treatment (IMT vs. PLA). Intervention $\times$ treatment interaction effects and within- group changes were further explored by analyzing IMT and PLA groups separately using two-way repeated-measures ANOVA. Distribution and variance homogeneity of the residuals from the ANOVA were evaluated using probability plots. Planned pairwise comparisons were made with paired repeated-measures $t$-tests with Bonferroni adjustment. Reliability was assessed using a CV calculated from a pooled mean of both groups and all trials. Statistical significance was set at $P<0.05$. Results are presented as means \pm SD.

\section{RESULTS}

Age (IMT vs. PLA: $27 \pm 7$ vs. $22 \pm 3$ yr), body mass $(80 \pm$ 6 vs. $74 \pm 7 \mathrm{~kg})$, height (181 \pm 5 vs. $177 \pm 4 \mathrm{~cm})$, and peak oxygen uptake $\left(52 \pm 6.2\right.$ vs. $\left.47 \pm 5.7 \mathrm{ml} \cdot \mathrm{kg}^{-1} \cdot \mathrm{min}^{-1}\right)$ were not different between groups. Maximum power output (378 \pm 21 vs. $336 \pm 23 \mathrm{~W})$ and $\dot{\mathrm{V}}_{\text {Eeak }}(154 \pm 19$ vs. $120 \pm 27 \mathrm{l} / \mathrm{min})$ were higher $(P<0.05)$ for the IMT group. All other preintervention measurements were not different between groups. All responses remained unchanged from rest during PASSIVE trials (data not shown).

Pulmonary function and maximal inspiratory pressure. Preintervention pulmonary function (data not shown) and MIP were within normal limits. Compliance with the intervention was excellent in both IMT and PLA groups with $96 \pm 1$ and $93 \pm$ $1 \%$ of sessions completed, respectively. Pulmonary function was unchanged in both groups postintervention, whereas MIP increased from $168 \pm 49$ to $202 \pm 39 \mathrm{cmH}_{2} \mathrm{O}(+24 \pm 16 \%)$ after IMT $(P<0.01)$. Inspection of training diaries revealed habitual whole-body training remained constant in both groups.

Breathing and respiratory muscle recruitment patterns. There were no main effects of intervention for breathing and respiratory muscle recruitment pattern data during MSVV (Table 1 and Fig. 2). This shows that participants were able to accurately mimic the breathing and respiratory muscle recruitment patterns commensurate with heavy cycling exercise and that these factors were the same before and after IMT and PLA. The intertrial $\mathrm{CV}$ for $\mathrm{P}_{\text {dipeak }}$ at rest was $<7 \%$.

Plasma cytokine concentrations. There was a main effect of time $(P<0.01)$ for plasma IL-1 $\beta$ and IL-6 concentrations and a strong trend $(P=0.067)$ for plasma IL-1ra concentration during MSVV (Fig. 3). There were no other main or interaction effects for plasma IL-1 $\beta$ and IL-ra concentrations, whereas there was a main effect for intervention $(P=0.048)$ and intervention $\times$ treatment $(P=0.025)$ and intervention $\times$ time $\times$ treatment $(P=0.024)$ interactions for plasma IL-6 concentration (Fig. 3). To explore the nature of these interactions, a subsequent two-way ANOVA performed separately for IMT and PLA groups revealed that plasma IL-6 concentration was reduced after IMT (main effect of intervention, $P=0.029$ ), whereas there was no change after PLA $(P=0.753)$.

DNA damage in PBMC. Preintervention alkaline, FPG and ENDO III Comets at rest during MSVV were 9.2 \pm 4.6, $15.6 \pm 6.3$, and $13.4 \pm 5.5 \%$ DNA in Comet tail for the IMT group and 8.2 $\pm 3.3,17.8 \pm 7.3$, and $10.8 \pm 2.0 \%$ DNA in Comet tail for the PLA group. There were no main or interaction effects demonstrating that MSVV did not induce DNA damage in PBMC.

Twitch transdiaphragmatic pressures. A plateau (i.e., no significant increase in amplitude with increasing stimulation intensity) in $\mathrm{P}_{\text {ditw }}$ and $\mathrm{M}$-wave amplitude (data not shown) was observed in response to supramaximal BAMPS, indicating 
Table 1. Physiological responses and dyspnea during maximum sustainable voluntary ventilation for inspiratory muscle training (IMT) and placebo (PLA) groups

\begin{tabular}{|c|c|c|c|c|}
\hline & \multicolumn{2}{|c|}{ IMT } & \multicolumn{2}{|c|}{ PLA } \\
\hline$\dot{\mathrm{V}} \mathrm{E}, 1 / \mathrm{min}$ & $109 \pm 20$ & $109 \pm 15$ & $99 \pm 19$ & $98 \pm 19$ \\
\hline $\mathrm{V}_{\mathrm{T}}, 1$ & $2.75 \pm 0.68$ & $2.71 \pm 0.68$ & $2.70 \pm 0.43$ & $2.66 \pm 0.41$ \\
\hline$f_{\mathrm{B}}$, breaths $/ \mathrm{min}$ & $42 \pm 10$ & $42 \pm 10$ & $37 \pm 6$ & $37 \pm 6$ \\
\hline $\mathrm{T}_{\mathrm{I}} / \mathrm{T}_{\text {ТОт }}$ & $0.49 \pm 0.04$ & $0.48 \pm 0.05$ & $0.50 \pm 0.03$ & $0.50 \pm 0.02$ \\
\hline$\left[\mathrm{La}^{-}\right]_{\mathrm{B}}, \mathrm{mmol} / 1$ & $1.37 \pm 0.57$ & $1.21 \pm 0.40$ & $1.29 \pm 0.41$ & $1.19 \pm 0.48$ \\
\hline$f_{\mathrm{C}}$, beats $/ \mathrm{min}$ & $84 \pm 9$ & $80 \pm 10$ & $74 \pm 6$ & $74 \pm 13$ \\
\hline $\mathrm{SpO}_{2}, \%$ & $99 \pm 1$ & $99 \pm 1$ & $99 \pm 1$ & $99 \pm 1$ \\
\hline Dyspnea & $5.4 \pm 2.8$ & $2.8 \pm 1.0$ & $3.9 \pm 2.4$ & $4.2 \pm 3.0$ \\
\hline
\end{tabular}

$\dot{\mathrm{V}} \mathrm{E}$, minute ventilation; $\% \dot{\mathrm{V}}_{\mathrm{E} \text { eak }}$, percentage of peak minute ventilation achieved during the preintervention maximal incremental cycling test; $\mathrm{V}_{\mathrm{T}}$, tidal volume; $f_{\mathrm{B}}$, breathing frequency; $\mathrm{T}_{\mathrm{I}} / \mathrm{T}_{\mathrm{TOT}}$, duty cycle; $\left[\mathrm{La}^{-}\right]_{\mathrm{B}}$, blood lactate concentration; $\mathrm{PCO}_{2}$, partial pressure carbon dioxide; $f_{\mathrm{C}}$, cardiac frequency; $\mathrm{SpO}$, arterial oxygen saturation. See text for description of analyses.

maximal depolarization of the phrenic nerves. There were no main or interaction effects for nonpotentiated $\mathrm{P}_{\mathrm{ditw}}$ during MSVV (data not shown). There was a main effect of time $(P<$ 0.01 ) for potentiated $\mathrm{P}_{\mathrm{ditw}}$, demonstrating evidence of diaphragm fatigue, but there were no other main or interaction effects (Fig. 4). Compared with baseline measures, preintervention potentiated $\mathrm{P}_{\mathrm{ditw}}$ was reduced by 15 and $20 \%$ at $<15$ min for IMT and PLA groups, respectively. The inter- and intratrial $\mathrm{CV}$ for baseline nonpotentiated $\mathrm{P}_{\mathrm{ditw}}$ and potentiated $\mathrm{P}_{\mathrm{ditw}}$ was $<8 \%$.

Additional measurements. There were no main effects of time for $\mathrm{pH}, \mathrm{PCO}_{2}$, and $\mathrm{SaO}_{2}$, showing that these variables were maintained at rest during MSVV (Table 1). There were main effects of time $(P<0.01)$ for $\left[\mathrm{La}^{-}\right]_{\mathrm{B}}, f_{\mathrm{C}}$ and dyspnea during MSVV (Table 1). There were no other main or interaction effects for $\left[\mathrm{La}^{-}\right]_{\mathrm{B}}$ or $f_{\mathrm{C}}$, whereas there were main effects of intervention $(P=0.034)$ and intervention $\times$ treatment $(P=$ $0.011)$ and intervention $\times$ time $\times$ treatment $(P=0.007)$ interactions for dyspnea during MSVV (Table 1). To explore the nature of these interactions, a subsequent two-way ANOVA performed separately for IMT and PLA groups revealed that dyspnea was reduced after IMT (main effect of intervention, $P=0.018$ ), whereas there was no change after PLA $(P=0.617)$.

Correlations among plasma IL-1 $\beta$ and IL-6 increases and selected variables during MSVV. There was a moderate negative correlation between the peak percentage increase from resting values in plasma IL-1 $\beta$ concentration and mean percentage of $\dot{\mathrm{V}} \mathrm{E}_{\text {peak }}$ achieved during the preintervention maximal incremental cycling test $\left(\% \dot{V}_{\text {peak }}\right)(\mathrm{r}=-0.68, P=0.016)$ during MSVV. There were moderate to strong positive correlations between the peak percentage increase from resting values in plasma IL-6 concentration and mean $\dot{\mathrm{V}}_{\mathrm{E}}(\mathrm{r}=0.74$, $P=0.006)$ and $\% \dot{\mathrm{V}}_{\mathrm{E} \text { peak }}(\mathrm{r}=0.63, P=0.029)$ during MSVV. There were no correlations between the peak percentage increase from rest in each plasma cytokine and the reduction in $\mathrm{P}_{\mathrm{ditw}}$ following MSVV.

Dose-response relationship of plasma interleukin-6 concentration. We have also attempted to quantify the doseresponse relationship between the plasma IL-6 response and respiratory muscle work and $\dot{\mathrm{V}}$. Figure 5 combines the preintervention IL-6 responses from the present study with those measured in our previous study (42) (12 participants from IMT and PLA groups, 2 volitional hyperpnea trials, 24 observations) and shows moderate to strong positive correlations between the peak percentage increase from rest in plasma IL-6 concentration and mean PTP $_{\mathrm{di}}, \mathrm{PTP}_{\mathrm{e}}$, and $\dot{\mathrm{V}}_{\mathrm{E}}$ during $1 \mathrm{~h}$ of steady state (42) and maximal sustainable (present study) voluntary ventilation.

\section{DISCUSSION}

Main findings. The main findings of this study were that following MSVV, whereby participants undertook $1 \mathrm{~h}$ of volitional hyperpnea at rest that mimicked the breathing and respiratory muscle recruitment patterns commensurate with heavy cycling exercise, plasma IL- $1 \beta$ and IL- 6 concentrations were significantly increased and there was a strong trend for an increase in plasma IL-1ra concentration. The plasma IL-6 response was attenuated following IMT, whereas the plasma IL-1 $\beta$ response was unchanged. The mechanisms responsible for the increase in plasma IL- $1 \beta$ and IL- 6 concentration could not be fully established as 1 ) there was no increase in a systemic marker of oxidative stress (DNA damage in PBMC), and 2) although diaphragm fatigue was evident following MSVV, it was not related to the increase in plasma IL-1 $\beta$ and IL-6 concentrations. Finally, a dose-response relationship between the plasma IL-6 response and respiratory muscle work and $\dot{V}_{E}$ was established.

To our knowledge, we are the first to report the plasma IL-1 $\beta$, IL-1ra, and IL-6 response to MSVV. The increase in plasma IL-1 $\beta$ concentration following MSVV was of a similar magnitude to that reported following IRL at $75 \%$ MIP until task failure $(66,67)$, whereas the increase in plasma IL-6 concentration following MSVV was much greater. We are confident that the increases in plasma IL- $1 \beta$ and IL- 6 concentration observed during MSVV are not an artefact of the experimental conditions since plasma cytokine concentrations were unchanged during the PASSIVE trial.

Stimuli for interleukin-1 $\beta$ and interleukin-6. The lack of DNA damage in PBMC following MSVV suggests that systemic oxidative stress was not responsible for the increase in plasma IL- $\beta$ and IL- 6 concentrations following MSVV. However, it cannot be excluded that there was a local increase 

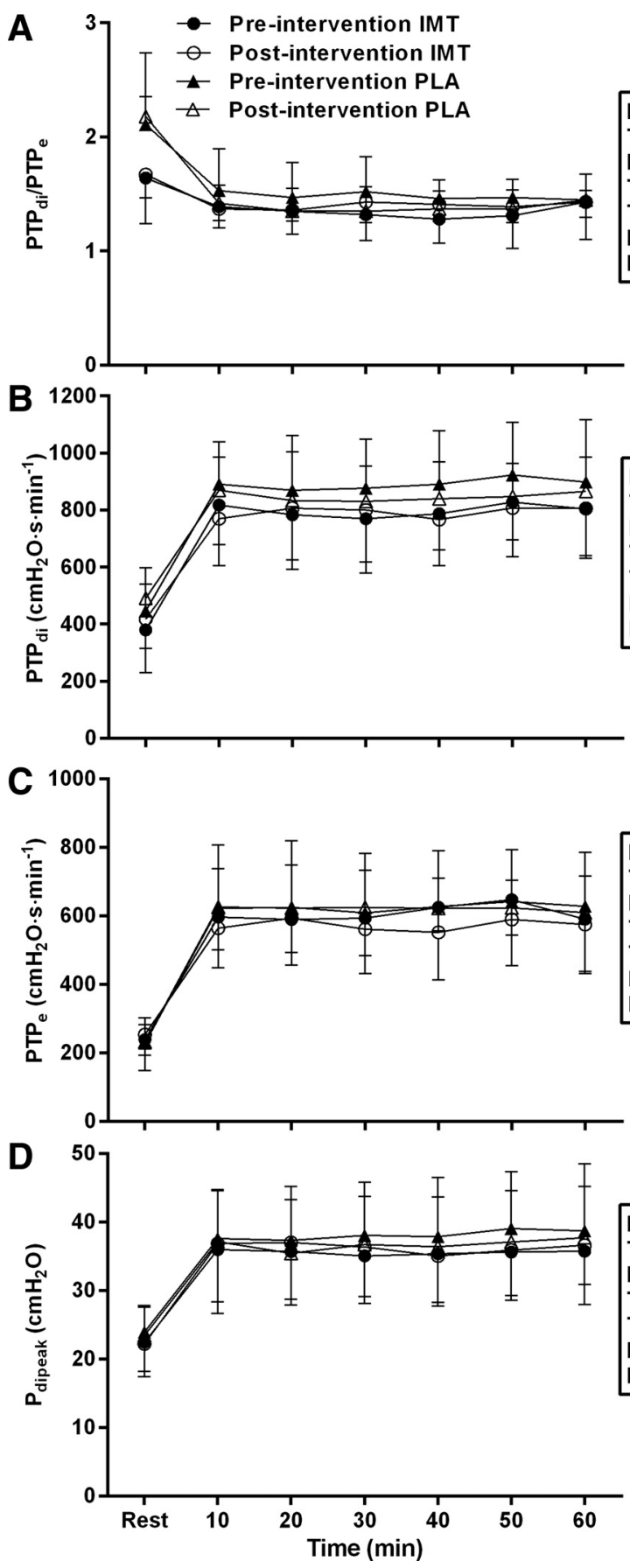

within the respiratory muscles. Oxidative stress due to enhanced generation of reactive oxygen and nitrogen species is an important regulator of IL- $1 \beta$ and IL- 6 production. Reactive oxygen species can upregulate IL-1 $\beta$ and IL-6 in the diaphragm of rats exposed to IRL (57). It could also be speculated that any localized increase in oxidative stress that might have occurred during MSVV was not sufficient to cause systemic DNA damage in PBMC. Lastly, we acknowledge that no single measurement of oxidative stress will summarize all the effects of MSVV and an effect may only be evident with a battery of markers (46).

As expected, there was evidence of diaphragm fatigue following MSVV. However, diaphragm fatigue does not

\section{Three-way ANOVA}

Intervention: $P=0.769$

$P=0.278$

Treatment: $P=0.432$

Treatment $\times$ Time: $P=\mathbf{0 . 8 1 4}$

Intervention $x$ Treatment: $P=0.370$

Intervention: $P=0.336$

Intervention $\times$ Time: $P=\mathbf{0 . 3 4 3}$

Treatment: $P=0.423$

Treatment: $P=0.454$

Intervention: $P=\mathbf{0 . 5 6 5}$

Intervention $\times$ Time: $P=0.365$

Treatment: $P=0.620$

ention $\times$ Treatment: $P=0.649$

Itervention: $P=0.456$

Time: $P=0.701$

ment: $P=0.738$

ntervention $x$ Time $\times$ Treatment: $P=0.565$
Fig. 2. The relative contribution of diaphragm to the inspiratory muscle pressuretime product $\left(\mathrm{PTP}_{\mathrm{di}} / \mathrm{PTP}_{\mathrm{e}}\right)(A)$, diaphragm pressure-time product $\left(\mathrm{PTP}_{\mathrm{di}}\right)(B)$, inspiratory muscle pressure-time product $\left(\mathrm{PTP}_{\mathrm{e}}\right)$ $(C)$, and peak transdiaphragmatic pressure ( $\left.\mathrm{P}_{\text {dipeak }}\right)(D)$ during maximum sustainable voluntary ventilation (MSVV) for inspiratory muscle training (IMT) and placebo (PLA) groups. Values are means $\pm \mathrm{SD}$. seem to be mechanistically linked with the increase in plasma IL-1 $\beta$ and IL-6 concentrations. This view is supported by the observations that the extent of diaphragm fatigue was not correlated with the magnitude of the plasma IL-1 $\beta$ and IL-6 concentration increase following MSVV, and that the extent of diaphragm fatigue remained remarkably consistent after IMT while the plasma IL-6 response was reduced. Confidence in our data is supported by the demonstration of supramaximal stimulation in $\mathrm{P}_{\text {ditw }}$ and $\mathrm{M}$-wave responses and excellent inter- and intratrial reliability in $\mathrm{P}_{\text {ditw }}$. Therefore, our data do not support the notion $(66,67)$ that diaphragm fatigue triggers IL-1 $\beta$ and IL-6 release. 
Fig. 3. Plasma interleukin-1 receptor antagonist (IL-1ra) (A), interleukin-1 $\beta$ (IL-1 $\beta$ ) $(B)$, and interleukin-6 (IL-6) $(C)$ concentrations during MSVV for IMT and PLA groups. Significant difference from rest $\left({ }^{*} P<0.05 ;{ }^{* *} P<0.01\right)$ and from the preintervention measurement at the same time point for the IMT group $\left({ }^{\dagger} P<0.05\right.$ $\left.{ }^{\dagger} P P<0.01\right)$. Values are means $\pm \mathrm{SD}$.

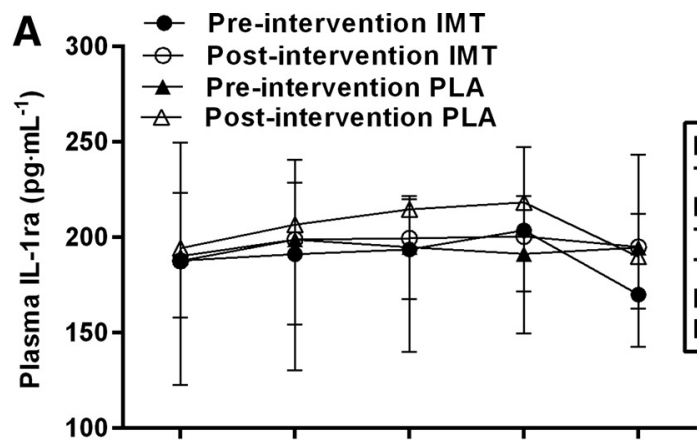

Three-way ANOVA

Intervention: $P=\mathbf{0 . 4 4 1}$

Time: $\boldsymbol{P}=\mathbf{0 . 0 6 7}$

Intervention $x$ Time: $P=\mathbf{0 . 8 5 6}$

Treatment: $\boldsymbol{P}=\mathbf{0 . 7 7 1}$

Treatment $x$ Time: $P=0.982$

Intervention $x$ Treatment: $P=0.870$

Intervention $\times$ Time $\times$ Treatment: $P=\mathbf{0 . 0 9 4}$

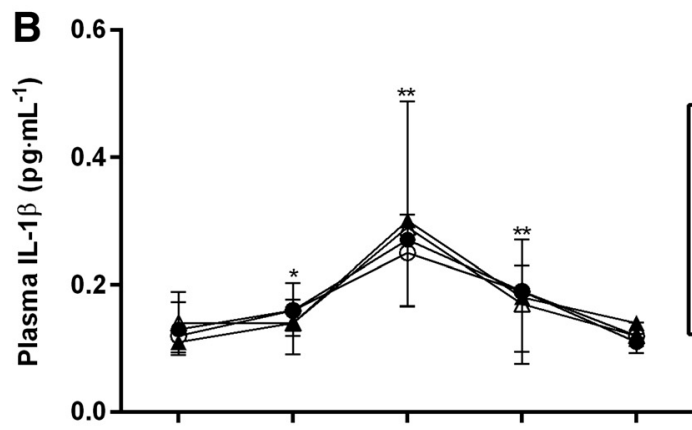

Intervention: $P=\mathbf{0 . 8 9 8}$

Time: $P<0.01$

Intervention $x$ Time: $P=\mathbf{0 . 9 7 1}$

Treatment: $P=0.932$

Treatment $\mathrm{x}$ Time: $\boldsymbol{P}=\mathbf{0 . 5 4 2}$

Intervention x Treatment: $P=0.993$

Intervention $\times$ Time $\times$ Treatment: $P=\mathbf{0 . 9 3 5}$

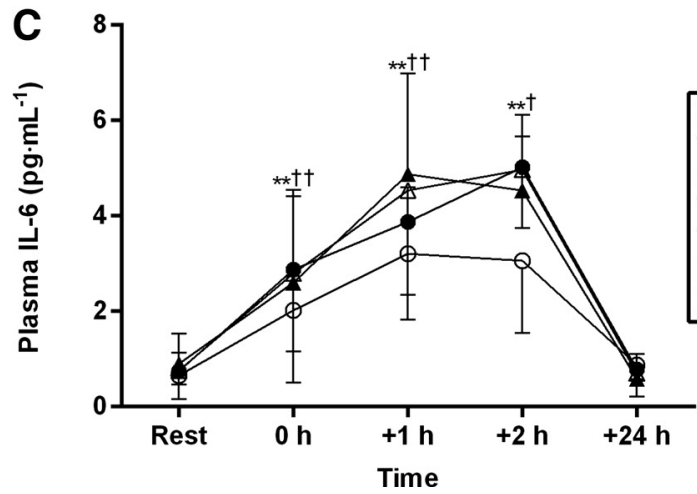

A more likely mechanism for the production of IL-6 may be a reduction in respiratory muscle glycogen content. Muscle glycogen depletion during prolonged and strenuous lowerbody exercise is a strong stimulus for enhanced IL-6 production by skeletal muscle fibers $(32,61)$. This notion is supported by the reduced diaphragm glycogen content of murines exposed to IRL (14) and whole-body exercise $(23,26)$.
Source of plasma interleukin-1 $\beta$ and interleukin-6. Contracting skeletal muscle accounts for most (but not all) of the increase in plasma IL-6 concentration observed during lowerbody exercise (63). Thus although our experimental model did not allow the source(s) of the increased plasma IL-1 $\beta$ and IL-6 following MSVV to be established, we attribute this increase to, primarily, increased IL- $1 \beta$ and IL- 6 release from contract-
Fig. 4. Potentiated transdiaphragmatic twitch pressure $\left(\mathrm{P}_{\mathrm{ditw}}\right)$ during MSVV for IMT and PLA groups. Significant difference from baseline $\left({ }^{* *} P<0.01\right)$. Values are means $\pm \mathrm{SD}$.

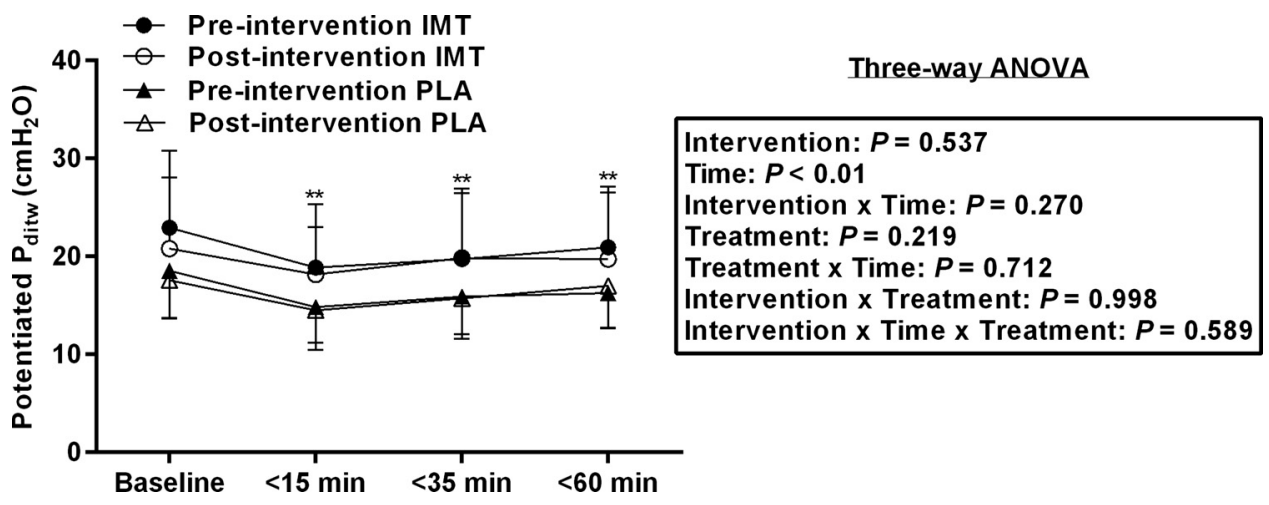



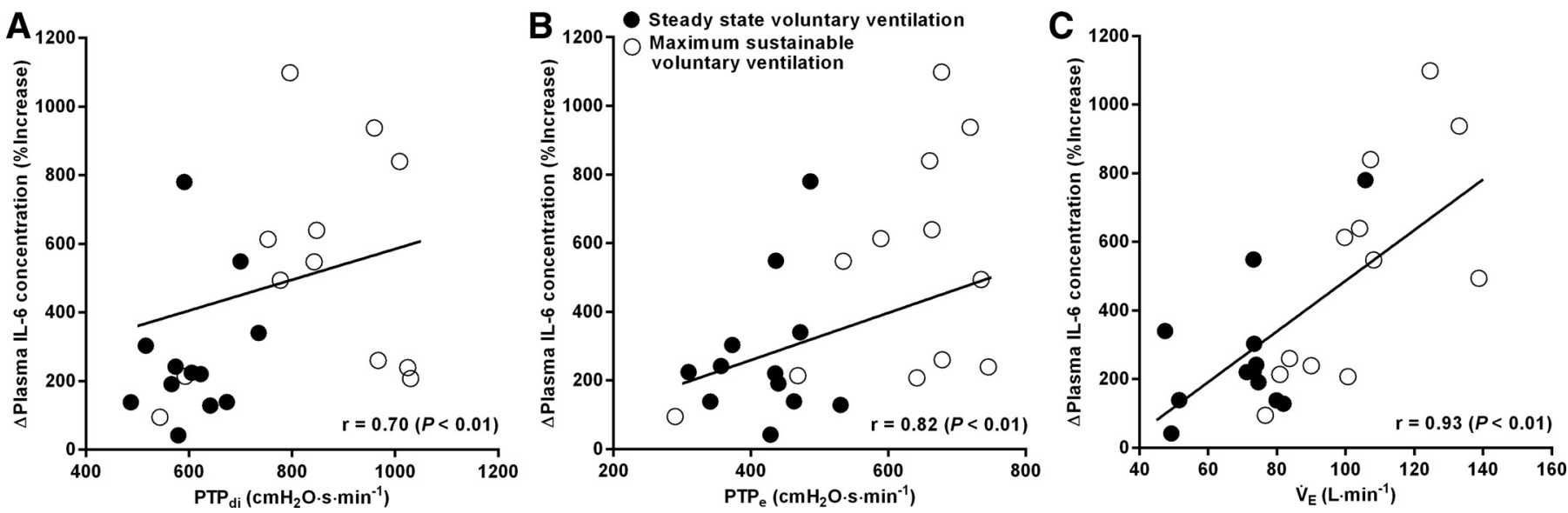

Fig. 5. Correlations between plasma interleukin-6 (IL-6) concentration and respiratory muscle work and minute ventilation (V்). The regression lines are for group mean data. The correlation coefficients (r) and associated $P$ values are for repeated observations within participants (5) where plasma IL-6 concentration (peak percentage increase from resting values), was treated as the dependent variable and the mean diaphragm pressure-time product $\left(\mathrm{PTP}_{\mathrm{di}}\right)(A)$, inspiratory muscle pressure-time product $\left(\mathrm{PTP}_{\mathrm{e}}\right)(B)$, and $\dot{\mathrm{V}}_{\mathrm{E}}(C)$ during $1 \mathrm{~h}$ of steady state $(42)$ and maximal sustainable (present study) voluntary ventilation are treated as the independent variables, and participant treated as the categorical variable.

ing respiratory muscles. This notion is consistent with the increased IL-1 $\beta$ and IL-6 mRNA and protein expression in the diaphragm of rats exposed to IRL $(56,57,65)$ and the higher IL-1 $\beta$ and IL- 6 protein expression in the external intercostals of patients with COPD compared with healthy controls (13).

Role of plasma interleukin-1 $\beta$ and interleukin- 6 . IL-1 $\beta$ may have a role within muscle repair and regeneration following injury. The IL-1 $\beta$ gene is activated with strenuous muscular contraction and the associated micro injury that occurs within the muscle stimulates quiescent resident macrophages to secrete IL-1 $\beta(11,17,21,51,64)$. IL-1 $\beta$ also stimulates proteolysis and acts as a chemoattractant for macrophages which can phagocytize cellular debris and provide a large source of growth factors which may stimulate myogenesis $(11,17,21$, $51,64)$. IL-1 $\beta$ can also impair striated muscle function and potentially reduce muscle contractility (37). IL-6 acts to stimulate lipolysis (67), hepatic glucose output (20), and glucose uptake in the contracting myocytes (10). IL-6 may also contribute to muscle repair and regeneration after injury which may involve a stimulatory effect on satellite cell proliferation $(33,64)$.

Effects of inspiratory muscle training on plasma interleukin-6 concentration. The present study is the first to demonstrate an attenuated plasma IL-6 response to MSVV following IMT. Reduced IL-6 production by inspiratory muscles following IMT may result from increases in basal levels of IL-6 receptor $\alpha(1,32)$ or antioxidant enzymes $(72)$, or reduced muscle glycogen utilization $(16,22)$ secondary to traininginduced increases in mitochondrial density (25). In our previous study, IMT did not attenuate the plasma IL-6 response to volitional hyperpnea that mimicked at rest the breathing and respiratory muscle recruitment patterns commensurate with cycling exercise undertaken at an estimated maximum lactate steady-state intensity (42). This suggests that there may be a threshold of ventilatory work above which respiratory muscle glycogen is significantly reduced and an effect of IMT on plasma IL-6 concentration is observed. Respiratory muscle metaboreflex activation $(55,60)$ may be attenuated by IMT $(39,70)$, thus promoting increased blood flow to the liver (20) and/or leg muscles (39). This may increase hepatosplanchnic uptake of IL-6 (20), whereas increased leg blood flow may result in less muscle glycogen utilization due to increased oxygen (4) and/or glucose (19) delivery. However, since the extent of diaphragm fatigue after MSVV was unchanged by IMT, leg muscles were inactive, and liver blood flow was unlikely to be affected by MSVV (during which cardiac output was presumably well below maximal), we feel that this explanation for reduced plasma IL-6 concentration is unlikely.

Dose-response relationship of plasma interleukin-6 concentration. We are the first to report a dose-response relationship between the plasma IL-6 response and respiratory muscle work and $\dot{V}_{E}$. These findings are broadly in line with the observation that increases in plasma IL-6 concentration are intensity dependent during whole-body exercise $(47,54)$. The dose-response may be explained by increased stimuli for IL-6 production such as greater oxidative stress or reductions in muscle glycogen content. Alternatively, increased IL-6 production may be attributed to the less efficient accessory inspiratory (and expiratory) muscles. The relative contribution of these muscles progressively increases (as the contribution from the diaphragm decreases) when ventilatory work rises $(27,53)$. When expressed relative to the size of the muscle group used, the arm muscles release greater amounts of IL- 6 than leg muscles and this is not directly related to release or uptake of exogenous substrate or muscle glycogen utilization (24) but may be due to differences in fiber type composition and vascular supply. In humans, the ratio of slow twitch fibers and number of capillaries per fiber are 50\% and 1.9 for the diaphragm, and $60 \%$ and 1.6 for the internal intercostals (44). Therefore, the less efficient accessory inspiratory muscles may also produce more IL-6 (relative to size) than the diaphragm due to differences in fiber type composition and vascular supply.

Application to asthma and COPD. Asthma attacks and COPD exacerbations lead to systemic inflammation due to inflammatory cytokines. The local source of these cytokines is not, however, fully understood. Some suggest that cytokines spill out from the lungs into the systemic circulation, whereas others suggest that multiple organs contribute $(34,58,71)$. Consistent with previous studies $(12,13,66,67)$ our data 
suggest that the respiratory muscles directly contribute to the systemic inflammation observed in these patients when respiratory muscle work is increased. Systemic inflammation in patients with asthma and COPD can contribute to increased mortality and reduced exercise capacity, health status, and quality of life $(34,71)$. However, based on the findings of the present study, it is attractive to speculate that IMT may reduce the plasma IL-6 response during periods of increased respiratory muscle work in patients with asthma and COPD. Respiratory muscle-derived cytokines in patients with severe COPD might impair muscle function and potentially reduce muscle contractility, while also playing a role in muscle repair/regeneration (50).

Conclusion. In conclusion, following MSVV plasma IL-1 $\beta$ and IL-6 concentrations were significantly increased, and there was a strong trend for an increase in plasma IL-1ra concentration. The plasma IL-6 response was reduced following IMT, whereas the plasma IL- $1 \beta$ response was unchanged. We also established that diaphragm fatigue and a systemic marker of oxidative stress were not related to the increase in plasma cytokine concentrations. Finally, a dose-response relationship exists between respiratory muscle work and $\dot{V}_{E}$ and increases in plasma IL-6 concentration.

\section{DISCLOSURES}

No conflicts of interest, financial or otherwise, are declared by the author(s).

\section{AUTHOR CONTRIBUTIONS}

Author contributions: D.E.M., M.A.J., Y.A.B., and G.R.S. conception and design of research; D.E.M., M.A.J., M.J.M., N.C.W., J.T.G., and G.R.S. performed experiments; D.E.M. analyzed data; D.E.M., M.A.J., and G.R.S interpreted results of experiments; D.E.M. prepared figures; D.E.M. drafted manuscript; D.E.M., M.A.J., Y.A.B., and G.R.S. edited and revised manuscript; D.E.M., M.A.J., M.J.M., N.C.W., J.T.G., Y.A.B., and G.R.S. approved final version of manuscript.

\section{REFERENCES}

1. Akerstrom TC, Krogh-Madsen R, Petersen AM, Pedersen BK. Glucose ingestion during endurance training in men attenuates expression of myokine receptor. Exp Physiol 94: 1124-1131, 2009.

2. Asahara H, Wistort PM, Bank JF, Bakerian RH, Cunningham RP. Purification and characterization of Escherichia coli endonuclease III from the cloned nth gene. Biochemistry 28: 4444-4449, 1989.

3. Babcock MA, Pegelow DF, McClaran SR, Suman OE, Dempsey JA. Contribution of diaphragmatic power output to exercise-induced diaphragm fatigue. J Appl Physiol 78: 1710-1719, 1995.

4. Bailey SJ, Romer LM, Kelly J, Wilkerson DP, DiMenna FJ, Jones AM. Inspiratory muscle training enhances pulmonary $\mathrm{O}(2)$ uptake kinetics and high-intensity exercise tolerance in humans. J Appl Physiol 109: 457-468, 2010.

5. Bland JM, Altman DG. Calculating correlation coefficients with repeated observations: Part 1-Correlation within subjects. BMJ 310: 446, 1995.

6. Boiteux S, Gajewski E, Laval J, Dizdaroglu M. Substrate specificity of the Escherichia coli Fpg protein (formamidopyrimidine-DNA glycosylase): excision of purine lesions in DNA produced by ionizing radiation or photosensitization. Biochemistry 31: 106-110, 1992.

7. Borg GA. Psychophysical bases of perceived exertion. Med Sci Sports Exerc 14: 377-381, 1982.

8. Brown PI, Sharpe GR, Johnson MA. Inspiratory muscle training abolishes the blood lactate increase associated with volitional hyperpnoea superimposed on exercise and accelerates lactate and oxygen uptake kinetics at the onset of exercise. Eur J Appl Physiol 112: 2117-2129, 2012.

9. Brown PI, Sharpe GR, Johnson MA. Inspiratory muscle training reduces blood lactate concentration during volitional hyperpnoea. Eur $J$ Appl Physiol 104: 111-117, 2008.
10. Brown PI, Sharpe GR, Johnson MA. Loading of trained inspiratory muscles speeds lactate recovery kinetics. Med Sci Sports Exerc 42: 1103-1112, 2010.

11. Cannon JG, Fielding RA, Fiatarone MA, Orencole SF, Dinarello CA, Evans WJ. Increased interleukin 1 beta in human skeletal muscle after exercise. Am J Physiol Regul Integr Comp Physiol 257: R451-R455, 1989.

12. Casadevall C, Coronell C, Ausin P, Martinez-Llorens J, Orozco-Levi M, Barreiro E, Gea J. Inflammatory cytokines and repair factors in the intercostal muscles of patients with severe COPD. Arch Bronconeumol 45: 279-285, 2009.

13. Casadevall C, Coronell C, Ramirez-Sarmiento AL, Martinez-Llorens J, Barreiro E, Orozco-Levi M, Gea J. Upregulation of pro-inflammatory cytokines in the intercostal muscles of COPD patients. Eur Respir J 30: 701-707, 2007.

14. Ciufo R, Dimarco A, Stofan D, Nethery D, Supinski G. Dichloroacetate reduces diaphragmatic lactate formation but impairs respiratory performance. Am J Respir Crit Care Med 164: 1669-1674, 2001.

15. Collins AR, Duthie SJ, Dobson VL. Direct enzymic detection of endogenous oxidative base damage in human lymphocyte DNA. Carcinogenesis 14: 1733-1735, 1993.

16. Croft L, Bartlett JD, MacLaren DP, Reilly T, Evans L, Mattey DL, Nixon NB, Drust B, Morton JP. High-intensity interval training attenuates the exercise-induced increase in plasma IL-6 in response to acute exercise. Appl Physiol Nutr Metab 34: 1098-1107, 2009.

17. Dennis RA, Trappe TA, Simpson P, Carroll C, Huang BE, Nagarajan R, Bearden E, Gurley C, Duff GW, Evans WJ, Kornman K, Peterson CA. Interleukin-1 polymorphisms are associated with the inflammatory response in human muscle to acute resistance exercise. $J$ Physiol 560: 617-626, 2004.

18. Dinarello CA. The role of the interleukin-1-receptor antagonist in blocking inflammation mediated by interleukin-1. N Engl J Med 343: 732-734, 2000.

19. Ebeling P, Bourey R, Koranyi L, Tuominen JA, Groop LC, Henriksson J, Mueckler M, Sovijarvi A, Koivisto VA. Mechanism of enhanced insulin sensitivity in athletes. Increased blood flow, muscle glucose transport protein (GLUT-4) concentration, and glycogen synthase activity. J Clin Invest 92: 1623-1631, 1993.

20. Febbraio MA, Ott P, Nielsen HB, Steensberg A, Keller C, Krustrup P, Secher NH, Pedersen BK. Hepatosplanchnic clearance of interleukin-6 in humans during exercise. Am J Physiol Endocrinol Metab 285: E397E402, 2003.

21. Fielding RA, Manfredi TJ, Ding W, Fiatarone MA, Evans WJ, Cannon JG. Acute phase response in exercise. III Neutrophil and IL-1 beta accumulation in skeletal muscle. Am J Physiol Regul Integr Comp Physiol 265: R166-R172, 1993.

22. Fischer CP, Plomgaard P, Hansen AK, Pilegaard H, Saltin B, Pedersen BK. Endurance training reduces the contraction-induced interleukin- 6 mRNA expression in human skeletal muscle. Am J Physiol Endocrinol Metab 287: E1189-E1194, 2004.

23. Green HJ, Ball-Burnett ME, Morrissey MA, Spalding MJ, Hughson RL, Fraser IG. Fiber type specific glycogen utilization in rat diaphragm during treadmill exercise. J Appl Physiol 63: 75-83, 1987.

24. Helge JW, Klein DK, Andersen TM, van Hall G, Calbet J, Boushel R, Saltin B. Interleukin-6 release is higher across arm than leg muscles during whole-body exercise. Exp Physiol 96: 590-598, 2011.

25. Hoppeler H, Fluck M. Plasticity of skeletal muscle mitochondria: structure and function. Med Sci Sports Exerc 35: 95-104, 2003.

26. Ianuzzo CD, Spalding MJ, Williams H. Exercise-induced glycogen utilization by the respiratory muscles. J Appl Physiol 62: 1405-1409, 1987.

27. Johnson BD, Babcock MA, Suman OE, Dempsey JA. Exercise-induced diaphragmatic fatigue in healthy humans. J Physiol 460: 385-405, 1993.

28. Johnson MA, Mills DE, Brown DM, Bayfield KJ, Gonzalez JT, Sharpe GR. Inspiratory loading intensity does not influence lactate clearance during recovery. Med Sci Sports Exerc 44: 863-871, 2012.

29. Johnson MA, Sharpe GR, Brown PI. Inspiratory muscle training improves cycling time-trial performance and anaerobic work capacity but not critical power. Eur J Appl Physiol 101: 761-770, 2007.

30. Johnson MA, Sharpe GR, Brown PI. Investigations of the lactate minimum test. Int J Sports Med 30: 448-454, 2009.

31. Johnson MA, Sharpe GR, McConnell AK. Maximal voluntary hyperpnoea increases blood lactate concentration during exercise. Eur J Appl Physiol 96: 600-608, 2006. 
32. Keller C, Steensberg A, Hansen AK, Fischer CP, Plomgaard P, Pedersen BK. Effect of exercise, training, and glycogen availability on IL-6 receptor expression in human skeletal muscle. J Appl Physiol 99: 2075-2079, 2005.

33. Kharraz Y, Guerra J, Mann CJ, Serrano AL, Munoz-Canoves P. Macrophage plasticity and the role of inflammation in skeletal muscle repair. Mediators Inflamm 2013: 491497, 2013.

34. Kirkham P, Rahman I. Oxidative stress in asthma and COPD: antioxidants as a therapeutic strategy. Pharmacol Ther 111: 476-494, 2006.

35. Klas JV, Dempsey JA. Voluntary versus reflex regulation of maximal exercise flow: volume loops. Am Rev Respir Dis 139: 150-156, 1989.

36. Kufel TJ, Pineda LA, Junega RG, Hathwar R, Mador MJ. Diaphragmatic function after intense exercise in congestive heart failure patients. Eur Respir J 20: 1399-1405, 2002.

37. Kumar A, Thota V, Dee L, Olson J, Uretz E, Parrillo JE. Tumor necrosis factor alpha and interleukin 1 beta are responsible for in vitro myocardial cell depression induced by human septic shock serum. $J$ Exp Med 183: 949-958, 1996

38. Marthandan S, Murphy MP, Billett E, Barnett Y. An investigation of the effects of MitoQ on human peripheral mononuclear cells. Free Radic Res 45: 351-358, 2011.

39. McConnell AK, Lomax M. The influence of inspiratory muscle work history and specific inspiratory muscle training upon human limb muscle fatigue. J Physiol 577: 445-457, 2006.

40. McLoughlin P, Popham P, Linton RA, Bruce RC, Band DM. Use of arterialized venous blood sampling during incremental exercise tests. $J$ Appl Physiol 73: 937-940, 1992.

41. Miller MR, Hankinson J, Brusasco V, Burgos F, Casaburi R, Coates A, Crapo R, Enright P, van der Grinten CP, Gustafsson P, Jensen R, Johnson DC, MacIntyre N, McKay R, Navajas D, Pedersen OF, Pellegrino R, Viegi G, Wanger J. Standardisation of spirometry. Eur Respir J 26: 319-338, 2005.

42. Mills DE, Johnson MA, McPhilimey MJ, Williams NC, Gonzalez JT, Barnett YA, Sharpe GR. The effects of inspiratory muscle training on plasma interleukin- 6 concentration during cycling exercise and a volitional mimic of the exercise hyperpnea. J Appl Physiol 115: 1163-1172, 2013.

43. Mills GH, Kyroussis D, Hamnegard CH, Polkey MI, Green M, Moxham J. Bilateral magnetic stimulation of the phrenic nerves from an anterolateral approach. Am J Respir Crit Care Med 154: 1099-1105, 1996.

44. Mizuno M. Human respiratory muscles: fibre morphology and capillary supply. Eur Respir J 4: 587-601, 1991.

45. Ostrowski K, Rohde T, Asp S, Schjerling P, Pedersen BK. Pro- and anti-inflammatory cytokine balance in strenuous exercise in humans. $J$ Physiol 515 (Pt 1): 287-291, 1999.

46. Palmieri B, Sblendorio V. Oxidative stress tests: overview on reliability and use. Part I Eur Rev Med Pharmacol Sci 11: 309-342, 2007.

47. Peake J, Wilson G, Hordern M, Suzuki K, Yamaya K, Nosaka K, Mackinnon L, Coombes JS. Changes in neutrophil surface receptor expression, degranulation, and respiratory burst activity after moderateand high-intensity exercise. J Appl Physiol 97: 612-618, 2004.

48. Pedersen BK, Febbraio MA. Muscle as an endocrine organ: focus on muscle-derived interleukin-6. Physiol Rev 88: 1379-1406, 2008.

49. Reichhold S, Neubauer O, Bulmer AC, Knasmuller S, Wagner KH. Endurance exercise and DNA stability: is there a link to duration and intensity? Mutat Res 682: 28-38, 2009.

50. Reid WD, Rurak J, Harris RL. Skeletal muscle response to inflammation-lessons for chronic obstructive pulmonary disease. Crit Care Med 37: S372-S383, 2009.

51. Robertson TA, Maley MA, Grounds MD, Papadimitriou JM. The role of macrophages in skeletal muscle regeneration with particular reference to chemotaxis. Exp Cell Res 207: 321-331, 1993.

52. Romer LM, McConnell AK. Specificity and reversibility of inspiratory muscle training. Med Sci Sports Exerc 35: 237-244, 2003.

53. Romer LM, Miller JD, Haverkamp HC, Pegelow DF, Dempsey JA. Inspiratory muscles do not limit maximal incremental exercise performance in healthy subjects. Respir Physiol Neurobiol 156: 353-361, 2007.
54. Scott JP, Sale C, Greeves JP, Casey A, Dutton J, Fraser WD. Effect of exercise intensity on the cytokine response to an acute bout of running. Med Sci Sports Exerc 43: 2297-2306, 2011.

55. Sheel AW, Derchak PA, Morgan BJ, Pegelow DF, Jacques AJ, Dempsey JA. Fatiguing inspiratory muscle work causes reflex reduction in resting leg blood flow in humans. J Physiol 537: 277-289, 2001.

56. Sigala I, Zacharatos P, Boulia S, Toumpanakis D, Michailidou T, Parthenis D, Roussos C, Papapetropoulos A, Hussain SN, Vassilakopoulos T. Nitric oxide regulates cytokine induction in the diaphragm in response to inspiratory resistive breathing. J Appl Physiol 113: 15941603, 2012.

57. Sigala I, Zacharatos $\mathbf{P}$, Toumpanakis D, Michailidou T, Noussia $\mathbf{O}$, Theocharis S, Roussos C, Papapetropoulos A, Vassilakopoulos T. MAPKs and NF-kappaB differentially regulate cytokine expression in the diaphragm in response to resistive breathing: the role of oxidative stress. Am J Physiol Regul Integr Comp Physiol 300: R1152-R1162, 2011.

58. Sinden NJ, Stockley RA. Systemic inflammation and comorbidity in COPD: a result of 'overspill' of inflammatory mediators from the lungs? Review of the evidence. Thorax 65: 930-936, 2010.

59. Singh NP, McCoy MT, Tice RR, Schneider EL. A simple technique for quantitation of low levels of DNA damage in individual cells. Exp Cell Res 175: 184-191, 1988.

60. St Croix CM, Morgan BJ, Wetter TJ, Dempsey JA. Fatiguing inspiratory muscle work causes reflex sympathetic activation in humans. $J$ Physiol 529 Pt 2: 493-504, 2000.

61. Steensberg A, Febbraio MA, Osada T, Schjerling P, van Hall G, Saltin B, Pedersen BK. Interleukin-6 production in contracting human skeletal muscle is influenced by preexercise muscle glycogen content. $J$ Physiol 537: 633-639, 2001.

62. Steensberg A, Fischer CP, Keller C, Moller K, Pedersen BK. IL-6 enhances plasma IL-1ra, IL-10, and cortisol in humans. Am J Physiol Endocrinol Metab 285: E433-E437, 2003.

63. Steensberg A, van Hall G, Osada T, Sacchetti M, Saltin B, Klarlund Pedersen B. Production of interleukin-6 in contracting human skeletal muscles can account for the exercise-induced increase in plasma interleukin-6. J Physiol 529 Pt 1: 237-242, 2000.

64. Tidball JG. Mechanisms of muscle injury, repair, and regeneration. Compr Physiol 1: 2029-2062, 2011.

65. Vassilakopoulos T, Divangahi M, Rallis G, Kishta O, Petrof B, Comtois A, Hussain SN. Differential cytokine gene expression in the diaphragm in response to strenuous resistive breathing. Am J Respir Crit Care Med 170: 154-161, 2004.

66. Vassilakopoulos T, Katsaounou P, Karatza MH, Kollintza A, Zakynthinos S, Roussos C. Strenuous resistive breathing induces plasma cytokines: role of antioxidants and monocytes. Am J Respir Crit Care Med 166: 1572-1578, 2002.

67. Vassilakopoulos T, Zakynthinos S, Roussos C. Strenuous resistive breathing induces proinflammatory cytokines and stimulates the HPA axis in humans. Am J Physiol Regul Integr Comp Physiol 277: R1013-R1019, 1999.

68. Verges S, Lenherr O, Haner AC, Schulz C, Spengler CM. Increased fatigue resistance of respiratory muscles during exercise after respiratory muscle endurance training. Am J Physiol Regul Integr Comp Physiol 292: R1246-R1253, 2007.

69. Wagner KH, Reichhold S, Neubauer O. Impact of endurance and ultraendurance exercise on DNA damage. Ann N Y Acad Sci 1229: 115-123, 2011

70. Witt JD, Guenette JA, Rupert JL, McKenzie DC, Sheel AW. Inspiratory muscle training attenuates the human respiratory muscle metaboreflex. J Physiol 584: 1019-1028, 2007.

71. Wouters EF, Reynaert NL, Dentener MA, Vernooy JH. Systemic and local inflammation in asthma and chronic obstructive pulmonary disease: is there a connection? Proc Am Thorac Soc 6: 638-647, 2009.

72. Yfanti C, Fischer CP, Nielsen S, Akerstrom T, Nielsen AR, Veskoukis AS, Kouretas D, Lykkesfeldt J, Pilegaard H, Pedersen BK. Role of vitamin $\mathrm{C}$ and $\mathrm{E}$ supplementation on IL-6 in response to training. $J \mathrm{Appl}$ Physiol 112: 990-1000, 2012. 